\title{
TREND BERHIJAB SYAR'I MUSLIMAH DALAM PERSPEKTIF KIAI
}

\author{
Siti Amaliati \\ Dosen Sekolah Tinggi Ilmu Tarbiyah Raden Santri Gresik \\ Email: amaliafillah@gmail.com
}

\begin{abstract}
Abstrak:
Tulisan ini hendak menganalisis secara utuh motivasi wanita muslimah memakai hijab syari serta mendapatkan gambaran kompleks tentang pemahaman kiai terkait motivasi muslimah berhijab syar'i. Fenomena hijab syar'i di kalangan wanita muslimah telah merebak di seluruh sudut-sudut wilayah mulai perkotaan hingga pedesaan. Hijab syar'i yang dipakaipun beragam corak dan motif, mulai dari penutup kepala yang menjuntai dari atas kepala hingga dada dan baju panjang hingga menutupi mata kaki. Gambaran model pakaian demikianlah yang menjadi kiblat muslimah dalam berbusana dan berpakaian saat ini. Idealisnya ketika seorang muslimah berhijab syar'i maka dapat dijadikan sebagai tolak ukur keshalihahan, ketaatan dan kepatutan seseorang dalam beragama. Namun realitanya ketika wanita muslimah berhijab syar' ${ }^{1}$ masih dilatarbelakangi dengan berbagai motivasi seperti motif teologis, motif psikologis, dan motif modis (trend fashion), maka hal ini menjadi pertanyaan yang menarik untuk dibahas tentang tampilan hijab syar'inya. Sementara Kiai merupakan individu yang dipandang memiliki andil yang cukup besar dan berpengaruh dalam masyarakat. Sosok kiai dapat menjadi panutan dan model bagi masyarakat di sekitarnya, baik dari sisi perkataannya maupun perbuatannya. Maka bagaimana pandangan seorang kiai dalam melihat dan menyikapi fenomena hijab syar'i di kalangan wanita muslimah. Pendekatan penelitian ini adalah kualitatif dengan menggunakan field reseach observasion dan bersifat deskriptif. Hasil dari observasi tersebut kemudian dijadikan sebagai data untuk mengetahui pandangan kiai tentang fenomena hijab syar'i. Hasil penelitian ini menunjukkan bahwa memakai hijab syar'i di kalangan wanita masih sebatas mengikuti trend berbusana kekinian, berhijab syar'i lebih pada motivasi psikologis dan kurangnya pengetahuan tentang keislaman
\end{abstract}

Kata Kunci ; Kata kunci: motivasi, hijab syar'i, kiai

\section{Pendahuluan}

Hijab atau jilbab menurut masyarakat luas biasanya disematkan pada identitas atau simbol agama Islam yang wajib dipakai oleh wanita muslim, dalam pandangan Islam yaitu wanita sudah baligh (dewasa). Hijab juga dijadikan legitimasi muslimah shalihah yang taat dan patuh dalam menjalankan syariat dan perintah beragama. Agama Islam sudah jelas dan gamblang menyeruhkan umatnya untuk menutup aurat perempuan hingga semua anggota tubuh wanita kecuali wajah dan telapak tangan,

\footnotetext{
${ }^{1}$ Abu Syuqqah, Busana Dan Perhiasan Wanita Menurut Al Quran Dan Al Hadist, cet ke I (Bandung: Mizan, 1998$), 20$
} 


\section{Tadrisuna}

Jurnal Pendidikan Islam dan Kajian Keislaman

dimaksudkan agar seorang wanita tidak memperlihatkan bagian lekuk tubuhnya dan menimbulkan fitnah bagi yang melihatnya di manapun dan kapanpun. Lebih spesifik tentang kegunaan hijab adalah pertama, untuk menutup aurat bagi wanita sebagai pelindung diri pribadinya dari fitnah, yang selain mahramnya. Kedua, menjaga dan melindungi kesucian, wanita lebih diterhormat dan lebih mulia. Ketiga, menjaga identitas sebagai wanita muslimah yang membedakan wanita satu dengan yang lainnya.

Trend model Jilbab atau hijab syar'i yang dikenal di Indonesia merupakan penutup kepala panjang mulai dari atas kepala hingga dada bahkan lutut disertai dengan pakaian yang tidak menampakkan lekuk atau bagian-bagian anggota tubuh mulai dari bahu hingga mata kaki. Kesan hijab syar'i yang kolot dan monoton telah mengalami pergeseran seiring dengan maraknya keanekaragaman rancangan hijab syar'i yang tetap tampak modis dan trendi, serta tentuntan banyak diminati oleh masyarakat. Seolah gayung bersambut atas fenomena tersebut para desainer pun berlomba-lomba merancang beragam model dan motif hijab yang menarik sehingga para konsumen tertarik untuk membelinya. Selain itu ditambah lagi dengan bahan yang digunakannya, perancang busana berusaha memberikan bahan yang terbaik sehingga nyaman bagi pemakainya.

Pada perkembangannya hijab syar'i tidak hanya dipakai oleh ibu-ibu saat pengajian saja. Namuan banyak perusahaan atau perkantoran yang memperbolehkan karyawannya menggunakannya saat aktivitas kerja. ini memperlihatkan dan menjadi indikasi bahwa pemakaian hijab syar'i sudah menjadi biasa dan lumrah bagi kebanyakan orang. Diperkuat lagi dengan pemerintah menetapkan Surat Keputusan (SK) No.100 tahun 1991 yang isi tentang memperbolehkan pengguna jilbab/hijab di seluruh lembaga pendidikan.

Maraknya hijab syar'i sangat kontradiktif ketika dihadapkan pada realita sosial yang ada, bahwa tidak sedikit muslimah yang memakai hijab syar'i namun hanya dipakai ketika ada kegiatan tertentu seperti mengikuti pengajian ataupun acara pesta, selebihnya ketika sudah di rumah mereka melepasnya meski bertemu dengan lawan jenis yang bukan muhrimnya. Sehingga hal tersebut kontradiktif dengan hakikat muslimah memakai hijab syar'i. Para muslimah tersebut mengenakan hijab syar'i dengan tujuan untuk menarik perhatian banyak orang dan menjadi pusat mode agar disebut seseorang yang fashionable maka dari sini terjadi pergeseran makna syar'i, yang harusnya melindungi diri dari pandangan-pandangan kemaksiyatan namun ini kebalikannya yang justru mendatangkan kemaksiyatan dan riya' bagi si pemakainya karena ingin dipandang lebih daripada yang lainnya, dan agar telihat tidak kuno atau kolot. Pada akhirnya berhijab syar'i para wanita muslimah hanya mengikuti trend bukan syariat dan tuntutan agama Islam.

Sehingga makna hijab syar'i di sini seolah-olah hanya sebagai tameng hiasan ketika bertemu dengan banyak orang atau di tempat umum. Maka, Perlu dipertanyakan motivasi mengenakannya apakah hanya sekedar mengikuti trend fashion kekinian atau murni karena kesadaran tuntutan agama Islam, atau hanya karena merasa nyaman memakainya. Oleh sebab itu wanita muslimah yang memakai hijab haruslah didasari pada keilmuan yang mendalam dan sebagai bentuk menjaga komitmen kepada Allah SWT, dimaksudkan agar yang mereka gunakan tersebut bermakna terhadap dirinya sendiri. Berhijab bukan karena zaman, trend, atau sedang dilihat banyak orang, namun berhijab merupakan 


\section{Tadrisuna}

cerminan identitas dari wanita muslimah yang dilandaskan atas dasar tuntutan ajaran agama Islam. Sehingga dimanapun dan kapanpun hijab selalu dipakai sebagai identitas diri muslimah yang sejati.

Hijab syar'i selalu erat hubungan dan kaitanya dengan agama Islam, maka melihat realitas tersebut tokoh agama dapat berperan aktif dalam upaya menciptakan dan memberikan edukasi Islami dalam permasalahan bagi wanita muslimah tersebut. Karena seorang tokoh agama cenderung disegani dan menjadi panutan dan tuntunan bagi masyarakat dalam pelaksanaan kegiatan-kegiatan keagamaan. selain itu, predikat yang selalu erat disematkan padanya adalah religius. Kiai diyakini memiliki kedudukan yang strategis, karena Kiai adalah merupakan orang yang memiliki pengetahuan keislaman yang amat mendalam. Oleh sebab itu setiap fatwa dan seruannya menjadi magnet tersendiri bagi masyarakat setempat untuk mengikutinya.

Berdasarkan permasalahan tersebut maka penulis dapat memberikan gambaran bahwa perlu dianalisis lebih mendalam tentang pandangan Kiai terhadap fenomena hijab syar'i di kalangan muslimah, tentang pandangan Kiai terkait dengan motivasi muslimah memakai hijab syar'i, dan hijab syar'i dalam tatanan ajaran agama Islam.

\section{Metode}

Artikel ilmiah ini menganalisis fenomena motivasi hijab syari di kalangan masyarakat dilihat dalam perspektif kiai. Bagaimana seorang kiai melihat fenomena motivasi hijab syari yang dipakai oleh kaum muslimah saat ini. Apa saja yang dilakukan oleh kiai ketika melihat realitas wanita muslimah yang berhijab syari namun tidak diimbangi dengan niatan yang baik atau motivasi menutup aurat sebagai kebutuhan tuntutan dan ajaran agama. Maka Kiai di sini dipandang perlu serta mempunyai peranan yang sangat penting dalam memberikan pengaruh religiuisitas pada masyarakat, agar masyarakat tetap berpegang teguh terhadap nilai-nilai ajaran agama Islam dalam segala hal, salah satunya dalam perpakaian.

Penelitian ini dilakukan dengan metode kualitatif, karena peneliti ingin mendapat gambaran menyeluruh bagaimana Kiai memandang fenomena hijab syar'i sekarang yang sedang trend di kalangan muslimah. Dengan menggunakan metode pengumpulan data wawancara langsung dan observasi langsung. Adapun subyek penelitian ini adalah mengambil informan dari Kiai yang bertempat tinggal di Desa Manyar Sidorukun Gresik berjumlah 3, Desa Manyar Sidomukti Gresik berjumlah 3 orang, dan Desa Manyar Rejo berjumlah 3 orang. Dan keterwakilan informan muslimah 6 orang dari masingmasing desa Teknik analisis data pada penelitian ini dilakukan dengan beberapa tahap diantaranya 1) mengumpulkan data 2) reduksi data 3) data display 4) penarikan kesimpulan serta verifikasi data. Prosedur teknik analisis data yang disebut sesuai teknik analisis data yang diungkapkan oleh Miles dan Huberman $(\mathrm{M} \& \mathrm{H})$ berikut alur penjelasannya: 


\section{Tadrisuna}

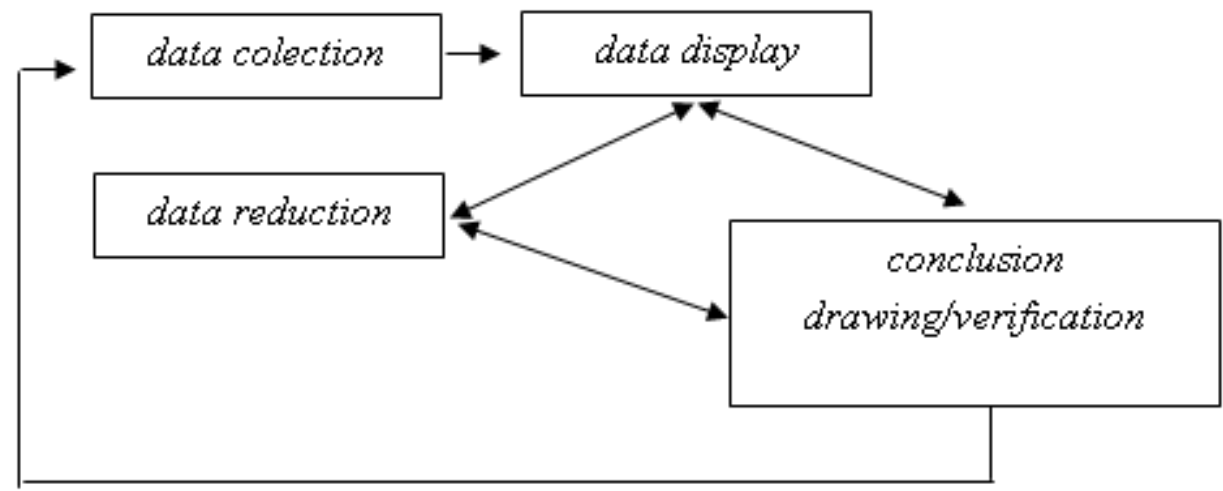

\section{Keterangan :}

1) Data colection yaitu kegiatan mengumpulkan semua data

2) Data reduction yaitu kegiatan melakukan pemilahan dan merangkum hal-hal yang pokok, memfokuskan hal-hal yang sangat penting yang sesuai dengan penelitian.

3) Data display yaitu kegiatan menarik simpulan dan keputusan pengambilan langkah (tindakan) dan penyajiannya dalam bentuk dan bersifat naratif. Dengan cara menyiapkan hasil wawancara dengan informan serta hasil observasi,dan dokumentasi dengan baik agar mudah dipahami oleh pembaca lain.

4) Penarikan simpulan dan verifikasi data (conclution Drawing and verification).

Perspektif yang digunakan dalam penelitian kualitatif salah satunya adalah perspektif fenomenologi. Penggunaan perspektif fenomenologi dimaksudkan untuk digunakan merekonstruksi kehidupan manusia ke dalam bentuk yang mereka secara alami mengalaminya sendiri. Pendekatan ini menginginkan berkolaboratifnya subjek peneliti dengan subjek pendukung objek penelitian. Keterlibatan subjek peneliti secara langsung di lapangan dan menghayatinya menjadi ciri utama penelitian pendekatan fenomenologi ${ }^{2}$.

Interpretasi terhadap prilaku subjek penelitian dilakukan dengan mengetahui apa yang ada dibenak seseorang mencakup pandangan seseorang tentang fenomena dan pemikiran seseorang tentang prilakunya, yang diperoleh berdasarkan wawancara mendalam sehingga memungkinkan dalam situasi ilmiah secara menyeluruh.

\section{Diskusi dan Hasil}

\section{Hijab Syar'i dalam Konteks Keislaman}

Hijab menurut bahasa Arab artinya penghalang, tutup atau tabir. Kata hijab lebih sering digunakan merujuk kepada kerudung yang dikenakan atau dipakai oleh wanita muslimah. Keilmuan Islam berpandangan lain, bahwa hijab lebih tepatnya ditujukan kepada bagaimana cara berbusana yang patut, pantas dan sesuai dengan tuntutan agama Islam. Maka, semua wanita muslim yang tidak memakainya mereka telah ingkar, menolak dan tidak menjalankan perintah dan hukum syariat Islam. Khususnya di Indonesia memakai hijab sama halnya dengan jilbab. Merujuk istilah yang diuraikan

\footnotetext{
${ }^{2}$ Noeng Muhajir, “Metodologi Penelitian Kualitatif”, Edisi II (Yogjakarta: Penerbit Rake Sarasin, 1996), 28
} 


\section{Tadrisuna}

didalam kamus besar bahasa Indonesia hijab diartikan sebagai tirai, tutup, pengahalang. Sedangkan menurut istilah lain yang dipaparkan oleh Yulian Purnama menyebutkan hijab menurut istilah adalah semua yang dilarang untuk ditampakkan dan dituntut untuk ditutupi dari pandangan orang lain, atau terlarang untuk menggapainya. Demikian pula penjelasan dari Guindi bahwa hijab diartikan sebagai "menutup, menyendiri, menyembunyikan, memasang tirai, memakai topeng, membentuk pemisahan,". Juga dirtikan sebagai "tutup, bungkus, tirai, cadar, layar, partisi" tabir, diding atau penutup. Hijab diartikan pula sebagai tiap-tiap yang menutupi hal-hal yang dituntut untuk tidak diperlihatkan menghalangi sesuatu yang memang tidak diperbolehkan untuk digapai atau diraihnya. ${ }^{3}$

Islam sendiri menjelaskan bahwa hijab merupakan tata cara berbusana yang pantas sesuai dengan syari'at atau tuntunan agama Islam. Menurut Nurul Haromaini Hijab adalah aturan-aturan yang diberlakukan dalam hubungan sosialisasi antara wanita dan pria yang merupakan etaborasi yang tidak diperbolehkan dilakukan dalam hubungan sosial. Hijab tidak hanya terbatas pada aturan dan perintah untuk wanita dalam menutup kepala dan wajah saja, melainkan suatu aturan dan sistem yang menyeluruh yang menjadi acuan dasar untuk dijalankan oleh pria dan wanita dalam bermu'amalah atau bersosialisasi untuk membangun masyarakat yang seutuhnya. ${ }^{4}$

Berbagai ungkapan istilah tersebut maka menurut hemat penulis bahwa hijab ataupun jilbab memiliki satu pengertian yang sama meskipun ada berbagai perbedaaan pandangan dari berbagai sudut istilah kebahasaan yang telah dikemukakan tersebut, dan dapat ditegaskan bahwa hijab atau jilbab merupakan alat yang digunakan seseorang untuk menutupi sesuatu agar tidak terlihat oleh pandangan mata, lebih spesifiknya merupakan alat untuk menutupi aurat dan tidak menonjolkan bagian-bagian anggota tubuh seorang wanita. Pada penggunaannya hijab dapat berupa pakaian mulai dari bahu hingga menjulur ke kaki seperti gamis dan jubah bersamaan dengan penutup kepala hingga menutupi dada, atau bahkan ada yang menutupi mulai kepala hingga lutut. Gambaran inilah yang akan menjadi titik tekan dalam penulisan artikel ilmiah ini. Untuk memperjelas gambaran tentang hijab syar'i maka penulis memberikan contoh seperti pada yang terlihat pada gambar berikut 1.1 dan 1.2. berikut ini:

\footnotetext{
${ }^{3}$ Yulian Purnama.’Makna Hijab, Khimar dan Jilbab”, (Buletin At Tauhid, 2015 https://muslim.or.id, diakses pada 5 Januari 2018)

${ }^{4}$ Nurul Haromaini, "Studi Analisis Pemaknaan Hijabers Community Surabaya terhadap Hijab dalam Film 99 Cahaya Di Langit Eropa”, (http://journal.unair.ac.id, diakses pada 8 Januari 2018). Commonline Departemen Komunikasi. vol. 3. No 3, 596
} 


\section{Tadrisuna}

Jurnal Pendidikan Islam dan Kajian Keislaman

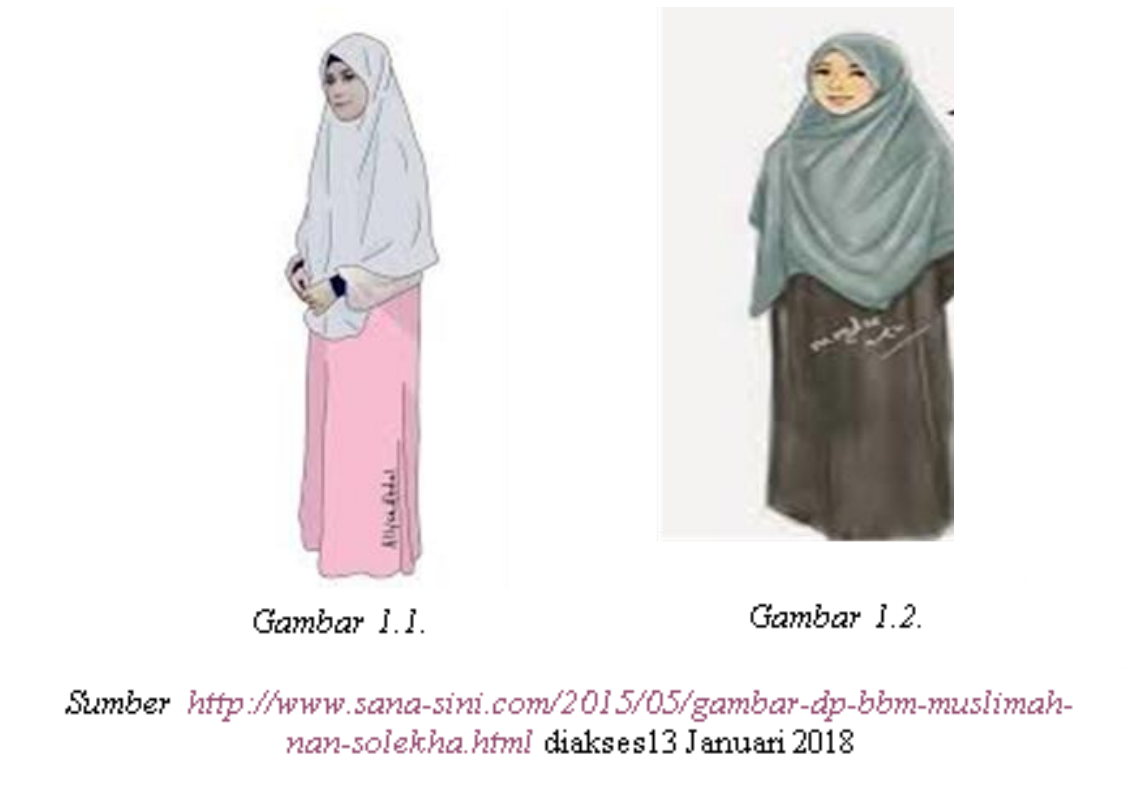

\section{Batasan Aurat Wanita Muslimah}

Beragam padangan para ulama tentang batasan aurat perempuan, namun sebelum berbicara tentang batasan aurat, perlu dipahami bersama makna aurat dalam pandangan Islam. Menurut pandangan Al Mubdi dalam kutipan Yulian Purnama bahwa aurat artinya segala hal yang harus ditutup ketika melaksanakan shalat dan dilarang bagi siapa saja untuk memperlihatkan bagi siapa saja di luar shalat. ${ }^{5}$ Dalil-dalil mengenai batasan aurat wanita di antaranya, Allah Ta'ala berfirman (yang artinya): "Katakanlah kepada wanita yang beriman: Hendaklah mereka menahan pandangan mereka, dan memelihara kemaluan mereka" (QS. An Nur: 31). Allah Ta'ala juga berfirman (yang artinya): "dan janganlah mereka memukulkan kaki mereka agar diketahui perhiasan yang mereka sembunyikan.” (QS. An Nur: 31). Allah Ta'ala juga berfirman (yang artinya): "Hai Nabi katakanlah kepada istri-istrimu, anak-anak perempuanmu dan istri-istri orang mu'min: "Hendaklah mereka mengulurkan jilbabnya ke seluruh tubuh mereka" (QS. Al Ahzab: 59). Juga diriwayatkan dari 'Aisyah radhiallahu'anha, beliau berkata, Asma' binti Abu Bakar pernah menemui Rasulullah shallallahu'alaihi wasallam dengan memakai pakaian yang tipis. Maka Rasulullah shallallahu'alaihi wasallam pun berpaling darinya dan bersabda, "wahai Asma', sesungguhnya seorang wanita itu jika sudah haidh (sudah baligh), tidak boleh terlihat dari dirinya kecuali ini dan ini", beliau menunjuk wajahnya dan kedua telapak tangannya". (HR. Abu Daud, hasan).

Berdasarkan petunjuk dalil di atas dan petunjuk-petunjuk lainnya, ulama berbeda pendapat mengenai batasan aurat bagi wanita. Ulama Imam Hanafi, Imam Maliki dan salah satu pendapat dalam madzhab atau pengikut Syafi'i berpendapat seluruh anggota tubuh wanita merupakan aurat yang tidak diperbolehkan untuk diperlihatkan terkecuali anggota tubuh wajah dan telapak tangan saja. Sedangkan ulama Imam Hambali salah satu pendapat dalam madzhab Syafi'i berpendapat lain bahwa seluruh anggota tubuh yang dimiliki wanita adalah aurat dan tidak terkecuali anggota tubuh wajah dan telapak

\footnotetext{
5 Yulian Purnama."Makna Hijab, Khimar dan Jilbab”, (Buletin At Tauhid, https://muslim.or.id, diakses pada 5 Januari 2018)
} 


\section{Tadrisuna}

Jurnal Pendidikan Islam dan Kajian Keislaman

tangan. Namun pendapat yang rajih (diterima), dan ini juga merupakan pendapat yang lazim diberlakukan oleh mayoritas masyarakat Muslimin di Indonesia, bahwa aurat wanita adalah semua anggota tubuh terkecuali wajah dan telapak tangan. Menurut hemat penulis bahwa keberagaman pendapat tentang batasan aurat tersebut wajar adanya. Namun, selain menutup aurat yang terlihat secara kasat mata yang terpenting adalah menutup aurat yang dibarengai dengan akhlaqul karimah semata-mata menutup aurat demi ajaran agama Islam. Sehingga perubahan kondisi lingkungan sekitar yang bermacam-macam tidak akan berpengaruh pada tampilan wanita muslimah.

\section{Kriteria Hijab Syar'i}

Sebagai gambaran umum tentang hijab syar'i, bahwa sebuah hijab dapat dikatakan syar'i jika telah memenuhi syarat yang sesuai dengan ketentuan al Quran dan al Hadist. Berikut ini beberapa ketentuan-ketetuan yang ada al Quran dan al Hadist:

1) Menutupi semua anggota tubuh terkecuali wajah dan telapak tangan. ${ }^{6}$ Sebelumnya telah dijelaskan dalam al Quran surat an Nuur ayat 31 dan surat al Ahzab ayat 59 bahwa muslimah wajib untuk berpakaian dan menutupi seluruh tubuhnya kecuali wajah dan telapak tangan.

2) Hijab tidak difungsikan sebagai perhiasan. Memakai hijab tidak dipakai agar orang lain memperhatikan si pemakainya, hijab tidak difungsikan sebagai perhiasan yaitu tidak menggunakan hijab dengan motif atau gambar-gambar yang mencolok pada hijab serta tidak menggunakan perhiasan yang dapat mempercantik tampilan hijab

3) Bahan yang diapakai hijab terbuat dari kain yang tebal dan longgar. Agar tidak terlihat bentuk atau lekuk tubuh pemakaian maka sebaiknya hijab heruslah besar serta dari kain yang tebal sehingga tidak transparan. Rasullullah SAW bersabda : " ada dua kelompok penghuni neraka yang belum pernah aku lihat, yaitu suatu kaum yang memiliki cambuk. layaknya ekor sapi yang digunakn untuk. mencambuk manusia, dan para perempuan yang berpakaian namun layaknya telanjang, berlenggak. lenggok. dan menggoda, kepalanya bagaikan punuk unta yang miring, mereka tidak masuk surga dan tidak mencium aromanya, padahal aroma surga tercium dan jarak sekian dan sekian (HR. Muslim).' Dalam hadits tersebut dijelaskan bahwa wanita yang memakai berpakaian namun terlihat telanjang adalah wanita yang memperlihatkan lekuk bagian-bagian tubuhnya yang memiliki arti menggunakan pakaian ketat dan tipis serta meggelung rambutnya ke atas atau menggunakan konde layaknya punuk unta adalah wanita yang tidak akan masuk surga.

4) Tidak menggunakan wewangaian. Ketika keluar rumah seorang wanita hendaknya tidak perlu menggunakan wewangian yang menyengat karena ini dapat menyebabkan fitnah bagi laki-laki yang tidak sengaja dilewatinya sebab dapat menimbulkan prasangka-prasangka.

5) Tidak menyerupai seperti pakaian laki-laki. Pakaian wanita muslimah yang dikenakan tidak diperbolehkan menyamai pakaian laki-laki. Maksudnya adalah seorang wanita yang menggunakan sepotong atau keseluruhan pakaian yang biasa digunakan oleh laki-laki, misalnya celana dan yang lainnya. ${ }^{8}$

'Dadi Ahmadi dan Nova Yohana, "Konstruksi Jilbab sebagai Simbol Keislaman",

(http:/ / ejournal.unisba.ac.id/index.php, diakses pada 8 Januari 2018). Jurnal Mediator Vol .8. No 2, 2007,244

${ }^{7}$ QQ Presika Jati Putri, Skripsi: Pengaruh Pemakaian Hijab Syari terhadap Interaksi dengan Lawan Jenis”. (Jakarta: Fakultas

Ilmu Tarbiyah dan Keguruan Uin Syarif Hidayatullah, 2017),16

${ }^{8}$ QQ Presika Jati Putri, "Pengarub Pemakaian Hijab Syari terhadap Interaksi dengan Lawan Jenis ", 17 


\section{Tadrisuna}

\section{Jurnal Pendidikan Islam dan Kajian Keislaman}

6) Bukan untuk mencari popularitas (libas syurah) maksudnya setiap pakaian yang digunakan hanya untuk mencari popularitas dan menarik perhatian orang lain agar tidak dianggap orang yang tidak mengikuti trend dan kuno (gengsi). Baik itu berupa jenis pakaian ataupun perhiasan yang mahal dari sisi harga, ataupun sebaliknya memakai pakaian yang sangat lusuh untuk menunjukan kesemua orang tentang sifat zuhud yang bertujuan riya atau pamer ( tidak melakukan zuhud secara ikhlas ). Rasulullah saw menjelaskan : "barangsiapa yang menegakkan pakaian syurah (untuk mencari popularitas) di dunia niscahya Allah akan menegakkan pakaian penghinaan pada hari kiamat"kemudian membakarnya dengan api neraka" (HR. Abu Dawud dan Ibnu Majjah).

Kriteria tersebut menggambarkan bahwa berhijab syar'i bukan untuk status sosial artinya tidak dipandang lebih oleh orang lain bagi si pemakainya. Namun, semata-mata karena tuntutan ajaran agama Islam.

\section{Motivasi Muslimah Berhijab Syar'i}

Segala tindak tanduk prilaku seseorang pasti didahului motivasi yang melatar belakangi untuk melakukannya, dari motivasi tersebut maka dapat mencerminkan prilaku seseorang. Sebelum mengulas lebih dalam motivasi, maka perlu memahami definisi motivasi itu sendiri. Motivasi asal dari kata motif yang dapat diterjemhkan sebagai kekuatan yang terdapat dalam diri masing-masing individu, yang menjadi penyebab seseorang tersebut melakukan tindakan.' Motif adalah keadaan kewajiban mendorong mengaktifkan, menggerakkan atau melakukan tindakan dan motif itulah yang memberikan arahan dan menyalurkan tindakan, sikap dan prilaku seseorang yang berkaitan dengan pencapaian tujuan baik tujuan organisasi maupun tujuan pribadi masing-masing anggota organisasi yang bersangkutan. ${ }^{10}$

Pendapat Sudirman A.M. yang oleh dikutip Muhamad Saprudin, Mushlihin dan Sari Narulita dalam 'jurnal Studi Al-Qur'an’ Vol.12, No. 2 , Tahun 2016 dijelaskan bahwa kata motif diterjemahkan sebagai kekuatan yang dapat memberikan dorongan seseorang untuk berbuat sesuatu. Motif dapat juga diarikan sebagai kekuatan penggerak dari dalam subjek untuk menjalankan aktivitas-aktivitas tertentu untuk tercapainya suatu tujuan. Bahkan motif dapat dipahami sebagai suatu keadaan (intern) kesiapsiagaan. Berakar dari kata motif tersebut, maka motivasi dipahami sebagai kekuatan penggerak yang aktif. Motivasi dikatakan aktif atau bergerak pada saat-saat tertentu terutama apabila dirasa kebutuhan untuk mencapai suatu tujuan sangat mendesak dilakukan. ${ }^{11}$

Motivasi seseorang dalam melakukan sesusatu dapat memberikan gambaran perbuatan, prilaku dan tujuan nyata seseorang. Sehingga jika dasar motivasi yang baik makan akan mencerminkan kebaikan, sebaliknya dengan prilaku yang tercela maka diawali dengan motivasi yang tercela pula.

\footnotetext{
${ }^{9}$ Hamzah B Unu, “Teori Motivasi dan Pengukurannya", (Jakarta: Bumi Aksara, 2008), 3

${ }^{10}$ Siagian Sondang P, "Teori Motivasi dan Aplikasinya”, (Jakarta: Rineka Cipta 2004),142

11 Sudirman A.M, "Interaksi dan Motivasi Belajar Mengajar", (Jakarta: Rajawali Pers. 2011), 73.
} 


\section{Tadrisuna}

Menurut Dadi Ahmadi dan Nova Yohana mengkategorikan motif-motif atau alasan seseorang ketika memutuskan untuk memakai hijab, berikut ini merupakan motif atau alasan seseorang memakai hijab syar'i:

1) Hijab atau jilbab dengan motif teologis yaitu menunjukkan bahwa memakai hijab atas alasan kewajiban dan tuntutan agama. ${ }^{12}$ Menurut pandangan Sriyanti (2005) yang dikutip Istiqomah menjelaskan bahwa alasan memakai hijab sebagai kewajiban agama. Mereka yang mengenakan hijab dapat memahami sebagai suatu kewajiban yang tidak dapat ditinggalkan. Pemakaian hijab seharusnya sesuai dengan aturan-aturan syariat, tidak hanya sebagai penutup rambut dan kepala, namun pemakaian hijab menurut mereka yaitu mengulurkan hijab sampai kedada dan menutupi lekuk tubuh yang dapat menimbulkan maksiyat bagi yang melihatnya. ${ }^{13}$ Pemakaian hijab dimaksudkan menjaga kehormatan dengan menutup aurat dari pandangan orang-orang yang bukan muhrimnya. Perempuan yang mengenakan hijab seperti ini akan selalu konsisten dalam berhijab dan berhati-hati dalam bergaul. Dalam hal ini hijab yang dipakai berdasarkan fungsi iman, di mana pakaian mencerminkan keimanan pemakai, bagaimana cara seseorang mengenakan pakaian bisa merupakan wujud dari keimanannya kepada Allah SWT. Umunya perubahan seseorang dalam berpakaian menjadi busana yang lebih Islami menunjukkan adanya perubahan dalam penghayatan ajaran agama karena itu, pakaian akhirnya mencerminkan kualitas moral seseorang, lambang kesadaran dan keinsafan seseoran terhadap syariat agama. 14

2) Hijab atau jilbab dengan motif psikologis yaitu berhijab tidak lagi sebagai kewajiban agama, tetapi sebagai budaya dan habits (kebiasaan) yang apabila ditinggalkan atau tidak dipakai akan menjadikan kondisi hati dan jiwa tidak nyaman, dengan kata lain hijab membuat perasaa tenang bagi pemakainya. Bentuk hijab yang dikenakan tetap menutupi aurat namun dengan beragam motif, variasi dan disesuaikan dengan konteks dan fungsinya. Demikian juga dengan gaya hidup pemakainya lebih terbuka dan menyesuaikan dengan kondisi tertetentu.

3) Hijab atau jilbab dengan motif modis, yaitu pemakainya beranggapan bahwa hijab sebagai produk trend fashion yang selalu bisa berganti-ganti sesuai dengan perkembanga zaman. Bagi sebagian orang, mengenakan hijab memberi keuntungan-keuntungan secara fisik, seperti untuk menutupi cacat tubuh atau hanya sekedar ingin menarik perhatian dan respon dari orang disekitarnya. ${ }^{15}$

Setiap tidakan seseorang pasti tidak lepas motif-motif seperti yang telah dipaparkan diatas. Melalui motif-motif tersebut maka akan memberikan berdampak pada prilaku pemakainnya. Melalui motivasi ini pula seseorang memiliki daya dorong yang dapat menggerakkan serta mengarahkan keinginan dan prilaku seseorang dan segala bentuk kekuatan untuk menggapai dan meraih tujuan yang diinginkannya, yang datang dari kemauan memenuhi kebutuhannya.

\footnotetext{
${ }^{12}$ Dadi Ahmadi dan Nova Yohana, "Konstruksi Jilbab sebagai Simbol Keislaman”, 244

${ }^{13}$ Dadi Ahmadi dan Nova Yohana, "Konstruksi Jilbab sebagai Simbol Keislaman”, 245

${ }^{14}$ Dadi Ahmadi dan Nova Yohana, "Konstruksi Jilbab sebagai Simbol Keislaman", 246

15 Dadi Ahmadi dan Nova Yohana, "Konstruksi Jilbab sebagai Simbol Keislaman”, 245
} 


\section{Tadrisuna}

Jurnal Pendidikan Islam dan Kajian Keislaman

\section{Peran Kiai dalam Masyarakat}

Pembahasan yang berkaitan dengan ruang lingkup Kiai sebenarnya bukan hal yang baru, beberapa pemikiran tentang Kiai seperti yang dipaparkan oleh Clifford Geertz (1981) dalam bukunya yang berjudul 'Abangan, Santri, Priyayi Dalam Masyarakat Jawa' yang meneliti struktur-struktur sosial masyarakat Jawa di Mojokuto. Selain itu juga ada Hiroko Horikoshi (1987) dalam 'Kyai dan Perubahan Sosial'. Horikoshi (1987) menyebutkan bahwa Kiai merupakan pemimpin kharismatik dalam bidang agama, dia sangat fasih dan memiliki kemampuan yang cermat membaca pikiran para pengikutpengikutnya. ${ }^{16}$ Budaya masyarakat Muslim, Kiai adalah satu dari sekian kaum elit yang mempunyai posisi sangat terhormat dan mempunyai pengaruh besar pada kemajuan dan perkembangan masyarakat tersebut. Kiai menjadi salah satu orang yang memiliki nilai yang strategis dalam struktur sosial karena nilai ketokohannya sebagai sosok figur yang memiliki ilmu pengetahuan luas dan dalam dalam bidang ajaran Islam. Secara teologis Kiai dipandang oleh masyarakat sebagai figur yang mewarisi para Nabi (waratsat al-anbiya). Maka, Tidak mengherankan jika Kiai kemudian dijadikan sebagai sumber legitimasi dari setiap permasalahan yang dihadapi sedang masyarakatnya, tidak hanya pada aspek hukum-hukum keagamaan Islam, tapi juga hampir dalam semua aspek sendi-sendi kehidupannya masyarakat. ${ }^{17}$

Biasanya kiai selalu disematkan pada seseorang yang memiliki atau pendiri pondok pesantren, namun dalam pembahasan artikel ini pengertian Kiai lebih luas bukan hanya pengasuh pesantren namun seseorang yang paham secara komprehansif tentang ajaran agama Islam seperti ulama, guru ngaji, dai, ustadz. Kiai dianggap orang yang memiliki kompeten dan mengetahui secara detail ilmu keagamaan. Keilmuan Kiai di Indonesia selalu identik dan disematkan pada orang yang faham secara komprehensif tentang ilmu agama Islam. Oleh sebab itu tidak heran, masyarakat Indonesia yang notabene beragama Islam lebih menghormati Kiai.

Kiai merupakan seorang tokoh di dalam struktur tatanan sosial masyarakat dan merupakan pemimpin non-formal yang dapat mempengaruhi perubahan besar didalam masyarakatnya. Dikatakan perubahan besar karena struktur masyarakat yang diubah memang selalu searah dengan yang Kiai kehendaki karena didasarkan pada azas kepatuhan masyarakat kepadanya. Kelebihan yang dimiliki kiai inilah yang selanjutnya menjadikannya sebagai pemimpin dan penentu arah kehidupan sosial di dalam suatu masyarakat. Bahkan permasalahan-permasalahan yang dialami oleh masyarakat seringnya meminta pertimbangan dan pendapat Kiai. Oleh sebab itu kiai dalam masyarakat memiliki peranan yang beragam seperti tokoh agama yang meliputi peran spiritual, pendidikan, agent of change, dan sosial budaya. ${ }^{18}$

Martin Van Bruinessen berpendapat bahwa Kiai memiliki peran yang memainkan lebih dari hanya seorang guru. Peran Kiai lebih jauh yaitu bertindak sebagai seorang pembimbing spiritual keagamaan bagi sosial masyarakat yang taat dan memberi petuah dan nasehat terkait masalah

\footnotetext{
${ }^{16}$ Nurlatipah Nasir, "Kyai dan Islam dalam Mempengaruhi Perilaku Memilih Masyarakat Kota Tasikmalaya”. Jurnal Politik Profetik. Vol 6 Nomor 2. 2015, 29

${ }^{17}$ Nurlatipah Nasir, "Kyai dan Islam dalam Mempengaruhi Perilaku Memilih Masyarakat Kota Tasikmalaya”, 30

${ }^{18}$ Robby Darwis Nasution, "Kyai sebagai Agen Perubahan Sosial dan Perdamaian dalam Masyarakat Tradisional". Jurnal Sosiohumaniora. Vol. 19. No. 2. 2017,183
} 


\section{Tadrisuna}

Jurnal Pendidikan Islam dan Kajian Keislaman

kehidupan pribadi masyarakat, pemimpin ritual-ritual penting, yaitu sebagai pembaca doa ketika ada kegiatan-kegiatan penting ${ }^{19}$.

Bila dilihat dari sisi sosial, kekuatan Kiai terletak pada dua hal yaitu memiliki perasaan kemasyarakatan yang dalam dan tinggi serta selalu melandaskan sesuatu kepada kesepakatan bersama. Kedua hal inilah yang membentuk posisi Kyai dalam masyarakat menjadi sangat kuat, sehingga sosok seorang Kyai berpengaruh sangat kuat sebagai figur pemimpin informal. Kalau ditelusuri lebih jauh, salah satu faktor penyebab yang membentuk kebesaran Kiai adalah faktor teologis, karena di kalangan masyarakat muslim Kyai dianggap adalah keturunan Nabi. Selain itu, faktor karisma yang terbentuk secara ilmiah juga ikut menentukan tinggi rendahnya pengaruh.

Dengan kedudukan dalam struktur sosial yang diposisikan dalam tingkatan elite, kiai menjadi tumpuan bagi aspirasi dan kebutuhan masyarakat di sekitarnya dan sebagai objek mayarakat dalam memecahkan masalah, baik individu maupun golongan atau kelompok.

\section{Penelitian dan Pembahasan}

\section{Langkah 1}

Peneliti melakukan wawancara mendalam kepada enam informan Muslimah dan dimintai pendapat tentang hijab syar'i. Dari hasil wawancara tersebut didapatkan informasi bahwa mereka faham perempuan muslimah harus menutup aurat, namun menutup aurat hanya sebatas memakai busana atau dress panjang, memakai kerudung dan menutupi rambut. Keterbatasan dalam memahami batasan-batasan wanita muslimah mengenai aurat. Seperti yang kutipan yang diungkapkan Rodhiyah Alimah salah satu informan.

'Kebanyakan dari masyarakat disini kalau kepengajian, kepasar dan ketempat-tempat umum memakai hijab atau jilbab, jilbabnya pun menurut saya syar'i dan kerudungnya juga panjang menutup dada tapi ya begitu kalau sudah dirumah atau dikampung mereka sudab lepas tidak peduli meski bertemu atau terlibat lawan jenis saya juga sering seperti itu. disamping itu memakai pakaian gamis panjang dilengkapi dengan setelan kerudung panjang yang menjuntai sampai dada itu sekarang lagi trendnya'

Berdasarkan pengamatan peneliti, setiap aktifitas kebanyakan Masyarakat di desa Manyar Sidorukun, Manyar Sidomukti dan Manyar Rejo memakai hijab. Hijab yang dipakai kebanyakan gamis panjang dilengkapi dengan hijab panjang mulai dari menutupi kepala hingga dada, bahkan ada pula hijab yang menutupi lutut. Motif dan warna busananya pun beragam mulai dari bunga-bunga, polos, dan corak yang warna warni. Tampilan yang demikian menjadi gaya pada setiap aktifitas perempuan di tiga lokasi penelitian tersebut. Realita yang ada menjadi menarik adalah di tiga lokasi penelitian tersebut perempuan hanya menggunakan hijab pada saat ada acara-acara tertentu seperti pengajian, resepsi, arisan, ke masjid, bahkan ke pasar. Selain itu, tampilan wajah dilengkapi dengan make up dan sebagian dari mereka menggunakan perhiasan sebagai pelengkap tampilannya. Namun, ketika kembali ke rumah atau hanya sekedar ketika berada di sekitar lingkungan rumah mereka atau sudah tidak berkegiatan di tempat-tempat umum tersebut, maka mereka melepas atribut syar'inya meski bertemu dengan bukan muhrimnya seperti memakai pakaian kaos oblong dan bahkan membuka kerudung. 


\section{Tadrisuna}

Manyar Gresik merupakan kawasan yang terkenal dengan religiusitas masyarakatnya. Kebanyakan dari mereka faham dengan hukum dan aturan Islam. Namun, tidak menjamin kefahaman mereka diaplikasi dalam aktivitas pribadi yang religius. Dalam sesi wawancara tentang sejauh mana pengetahuan mereka tentang aurat perempuan dan batasannya. Informasi yang di dapat dari informan yaitu secara komprehensif mereka memahami aurat wanita muslimah dan sebagian faham batasan perempuan berhijab. Namun, hukum Islam tersebut berhadapan dengan kondisi budaya masyarakat setempat, dan kebutuhan masyarakat yang lebih mementingkan pada penampilan yang fashionable dan kekinian. Sehingga konsistenitas mereka dalam memakai hijab yang sesuai dangan aturan Islam belum terpraktikkan dengan benar. Demikian ini telihat keseharian masyarakat dalam berbusana dan berpenampilan.

Kriteria hijab syar'i menurut informan memberikan keterangan yang berbeda-beda sebagian dari mereka beranggapan bahwa hijab syar'i adalah hijab yang dipakai oleh perempuan saat ini, artinya tidak harus menutupi dada dan dipakai dalam keseharian. Menurut keterangan salah satu informan :

'Ya...kalau hijab syar'i kami memahaminya pokoknya menutup aurat, kalau kebanyakan disini sih...mamakai perbiasan dan wewangaian itu biasa, kalau punya perbiasan diapakai kalau tidak punya ya... tidak dipaksa semua tergantung apa yang dimilikinya'

Menurut kutipan wawancara tersebut maka dapat dianalisis bahwa kebanyakan masyarakat memahami berhijab syar'i hanya dari kulitnya saja, artinya berbusana dan berpakaian hanya sebatas pada tampilan luarnya saja. Belum pada substansi berpakaian seperti yang Dadi Ahmadi dan Nova Yohana bahwa berhijab syar'i haruslah total, mulai dari tampilan secara fisik ataupun nonfisik seperti tidak menggunakan wewangian, perhiasan yang mencolok dan sebagainya. Bertujuan agar tidak menarik perhatian orang lain terlebih lawan jenisnya. Sehingga dapat menjaga citra diri perempuan muslimah shalihah.

Motivasi memakai hijab syar'i berdasarkan data interview mendalam didapati bahwa keterangan sebagian dari informan memakai hijab syar'i secara fisik karena mengikuti trend busana kekinian dan modern. Tanpa harus memperhatikan aturan-aturan yang ada dalam berbusana dan berpenampilan. Sehingga apa yang dilakukan sudah menjadi kewajaran dalam lingkungan. Seperti kutipan interview informan berikut ini:

'kalau berbijab syar'i pada umumnya saja.....kalau berbijab seperti orang-orang yang berpakaian panjang, kerudungnya gede samapai lutut tidak boleh apakai wewangian dan perbiasan, bisa dianggap kelompok minoritas dilingkungan sekitar ini, jadi ya... sewajarmya saja, tapi ada juga yang seperti itu........tidak masalah yang penting kita tidak mengganggu satu sama lainnya babkan di sini juga ada yang pakai cadar (alat penutup sebagian muka) itu juga tidak apa-apa'

Dalam kutipan interview tersebut dapat dianalisis bahwa motivasi perempuan muslimah berhijab masih pada tataran menutup aurat karena trendi dan lingkungan setempat, bukan karena semata-mata perintah dan tuntutan agama Islam sebagai pribadi yang muslimah. Namun, didapati pula kelompok-kelompok yang menggunakan hijab syar'i sesuai dengan tata cara berbusana syar'i. 


\section{Tadrisuna}

Jurnal Pendidikan Islam dan Kajian Keislaman

\section{Langkah II}

Langkah ke II ini dilakukan dengan tujuan untuk merespon pendapat informan pada langkah I, sehingga dapat diketahui sisi padangan kiai mengenai hijab syar'i. Peneliti melakukan wawancara mendalam kepada tiga informan Kiai di tiga lokasi penelitian tersebut. Ketiga kiai tersebut memiliki kesepakatan pandangan dan pemikiran mengenai motivasi berhijab syar'i wanita muslimah saat ini. Para informan mengawali interview dengan melihat dari sudut pandang kajian historis tentang hijab syar'i.

Secara kajian historis, berhijab pada dasarnya bukanlah konsep dan budaya milik Islam seutuhnya, tradisi berkerudung telah ada jauh sebelum masa Nabi SAW dan telah menjadi tradisi berbusana santun dan tertutup dikalangan wanita-wanitayang telah hidup jauh sebelum kelahiran Nabi Muhammad SAW. Tentunya ini mengindikasikan bahwa hijab pada waktu itu merupakan salah satu pakaian yang digunakan oleh kalangan Nasrani, Yahudi, dan berbagai wanita dari suku, agama, dan ras dari seluruh lapisan masyarakat. Pada saat itu menggunakan bukan pada substansi ataupun tuntunan ajaran agama tertentu melainkan lebih dekat dengan etika dan estetika. Perintah maupun petunjuk dari Allah SWT atas perintah berhijab dalam Islam didasarkan pada dua ayat dalam Al-Qur'an yaitu QS. Al-Ahzab/33:59 dan QS. An Nur/24:31. Kedua ayat tersebut turun pasca peristiwa fitnah keji dan dahsyat terhadap Aisyah r.a yang dilakukan oleh Abdullah Ibn Saba' beserta teman-temannya dari kaum munafik yang ada di Madinah. Peristiwa terhadap Aisyah r.a ini disebut peristiwa Al-Ifk. Sehingga untuk mengakhiri harus ditegaskan dengan diturunkannya lima ayat yaitu (QS.AnNur/24:11-15) dengan maksud untuk mengembalikan dan membersihkan nama baik Aisyah r.a. Bermula dari peristiwa tersebut, maka turunlah ayat lain yang lebih cenderung memberikan batasan pada ruang gerak keluarga Nabi, terlebih dua ayat di atas. Ayat ini turun (QS. Al-Ahzab/59 dan QS. An-Nur/31), dikarenakan masyarakat Madinah saat itu berada dalam kondisi lingkungan yang tidak tentram, dikarenakan situasi perang yang secara terus menerus dan berkepanjangan. Pada kondisi tersebut kaum bangsawan banyak yang memakai jilbab dan hampir diantara kaum tersebut hampir tidak mendapatkan kejadian pelecehan seksual dari para lelaki nakal. Sehingga untuk melindungi harkat dan martabat masyarakat muslim, maka di perintahkanlah untuk memakai jilbab.

Konteks keIndonesiaan, memaknai hijab sebagai pakaian penutup kepala yang lebih dulu oleh masyarakat umum dikenal dengan istilah 'kerudung', namun tahun 1980 an lebih populer dan dikenal dengan sebutan 'jilbab'. Jilbab atau hijab di Indonesia mengalami kemajuan yang cukup cepat dan pesat. Mulai dari kerudung yang hanya menutup kepala, jilbab modis (berjilbab tapi masih memperlihatkan lekuk tubuhnya), hingga saat ini yang disebut dengan hijab syar'i yaitu berhijab yang dianggap sesuai dengan norma dan aturan ajaran-ajaran Islam yang sebenarnya dan menjadi ligitimasi dan pengakuan diri bagi pekaianya bahwa mereka mamakai hijab sesuai dengan ajaran Islam dan ketentuan dalam al Quran. Tidak ada kesepakatan tunggal di kalangan ulama Islam (sarjana Islam) dan fuqaha (ahli hukum Islam) yang berkaitan dengan kewajiban berhijab untuk para perempuan Muslimah. Pendapat tersebut diantaranya, ada yang mengharuskan, mewajibkan, ada pula yang membolehkan, dan ada juga yang tidak mewajibkan. Sepanjang pakaian tersebut dapat menutupi aurat, lekuk anggota tubuh dan dapat menghindari si pemakainya dari fitnah maka tidak menjadi persoalan. Para ulama hanya memberikan rambu-rambu tertentu bagi pakaian wanita muslimah. Ringkasanya, 


\section{Tadrisuna}

Jurnal Pendidikan Islam dan Kajian Keislaman

disyaratkan bagi perempuan berpakaian yang tidak menunjukkan bagian-bagian auratnya, tidak tembus pandang, tidak menggambarkan lekuk tubuhnya, dan tidak menarik perhatian orang lain.

Salah satu mulia tujuan berhijab adalah untuk menutup diri dan melindungi diri dari berhias di hadapan laki-laki ajnabi (non-mahram) untuk menghindari fitnah, maka tidak diperbolehkan menghiasi jilbab atau hijab dengan berbagai aksesories yang mencolok. Salah satu Kiai berpendapat bahwa Jilbab atau hijab yang Islami atau sesuai syariah itu adalah hijab yang menutupi, lebar dan panjang serta tidak terdapat lukisan, bordiran dan hiasan-hiasan dan tidak ada hiasan-hiasannya. Beliau juga berpendapat bahwa bahwa diperbolehkan seorang wanita menampakkan dan memperlihatkan wajah dan kedua telapak tangan. Namun beliau memebrikan peringatan bahwa pendapat tersebut didasari dengan syarat bagian wajah dan telapak tangan perempuan tidak terdapat perhiasan yang dapat menarik perhatian orang lain atau menimbulkan maksiat. Apabila terdapat perhiasan pada dua bagian tubuh tersebut contohnya cincin yang disematkan dijari, make up berlebihan, dan lain-lain maka keduanya harus ditutupi dan tidak diperbolehkan untuk diperlihatkan, berdasarkan keumuman firman Allah ta'ala, “... dan janganlah mereka menampakkan perhiasannya”. Selanjutnya, tujuan yang paling utama perintah memakai jilbab yaitu sebagai penutup perhiasan. Oleh karena itu, jilbab yang dipakai wanita muslimah tidak boleh diperindah dengan perhiasan yang menyilaukan mata sehingga menarik perhatian dan hasrat pandangan kaum laki-laki. Fenomena yang terjadi di masyarakat adalah kebanyakan seorang muslimah ketika keluar rumah atau ke tempat-tempat umum banyak diantara mereka memperindah pakaian yang dikenakannya, contohnya adalah hiasan bordiran warna-warni, payet yang berkilau, pita sulam emas dan perak. Semua perhiasan tersebut dapat menyilaukan mata bagi siapa saja yang memandangnya. Satu hal lagi yang tidak kalah pentingnya adalah, agar dapat tercapai tujuan tertutupnya aurat, maka jilbab yang dipakai harus berupa kain yang tebal, tidak transparan yang dapat memperlihatkan warna kulit dan rambut, serta tidak membentuk bagian-bagian lekuk tubuh pemakainya. Banyak didapati bahan pakaian dengan kain yang tebal namun sangat halus ketika dipakai melekat pada tubuh, atau karena ukurannya yang sangat ketat sehingga nampak lekuk bagian-bagian tubuh pemakai.

Motivasi wanita muslimah berhijab saat ini lebih banyak karena ingin dipandang oleh orang lain agar tidak ketinggalan jaman, terlihat lebih fashionable, dan mengikuti busana masa kini dan tidak kolot. Apalagi kaum wanita tersebut ada dalam sebuah komunitas atau kelompok-kelompok pertemuan. Maka seolah-olah wajib mengikuti apa-apa yang di putuskan dalam komunitas tersebut. Maka tidak heran kalau masih banyak wanita muslimah lepas-pakai hijabnya dengan dalih ketidasiapan dalam berhijrah dengan berhijab. Padahal kalau hanya motivasi riligiuisitas saja yang selalu menjadi pegangan dalam berhijab maka apapun keadaannya tidak akan lepas-pakai hijab tersebut. Karena telah menjadi bagian dalam menjalankan syariat dan ajaran Allah SWT.

Selain motivasi dan alasan seseorang berhijab syari dapat dilatar belakangi oleh beberapa sebab, menurut Kiai Syihab salah satu informan berpendapat, beberapa alasan wanita dalam memakai hijab diantaranya 1) dengan kalimat "Saya perlu mempersiapkan diri berhijab Syar'i" padahal dalam konteks ajaran Islam Nabi Shallallahu'alaihi Wassallam bersabda, "Sesungguhnya agama itu mudah" (HR. Bukhari). Dari hadits tersebut kebanyakan ulama menjelaskan bahwa perintah yang ada dalam Islam itu pasti semua manusia mampu dan mudah melakukannya. Demikian dengan berhijab, jika kita renungkan dan pikirkan sebenarnya tiadak ada yang sulit dalam menjalankan perintah tersebut dan 


\section{Tadrisuna}

siap kapan saja untuk dilakukan. 2) dengan kalimat "banyak wanita berhijab syar'i yang akhlaknya buruk, tidak sepadan dengan hijabnya”. Wanita muslimahpun berpotensi melakukan dosa dan lupa karena itu merupakan bagian dari manusiawinya. Hal ini terlepas dari wanita tersebut berhijab atau belum. Memakai hijab tidak memberikan jaminan seorang muslimah tidak melakukan dosa. Namun akhlak yang baik itu wajib, baik sudah berhijab atau belum. Dan berhijab merupakan kewajiban, tidak memandang akhlak sudah baik atau belum. 3) dengan kalimat "Saya belum dapat hidayah" Hidayah itu dicari, bukan ditunggu. Allah Ta'ala berfirman (yang artinya): "Orang-orang yang bersungguhsungguh mencari keridhaan Kami, sungguh akan kami tunjukan kepada jalan Kami” (QS. Al an-Kabut: 69). Oleh karena itu berhentilah menunggu hidayah, mulailah mencari hidayah. Bahkan memakai hijab adalah salah satu bentuk kesungguhan seorang muslimah dalam mencari keridhaan Allah.

Menurut hasil informasi dari salah satu informan menjelaskan bahwa pernah melakukan bentuk-bentuk motivasi kepada wanita (masyarakat) dalam berhijab syar'i (tidak lepas pakai) agar tetap konsisten (istiqamah) berhijab. Pertama, dakwah secara langsung di setiap kesempatan seperti ketika pengajian, pertemuan rutin, kultum setelah shalat berjamaah di mushallah-mushallah. Kedua, dakwah secara tidak langsung yaitu dakwah yang dilakukan tidak secara langsung bertatap muka seperti melalui pesan singkat (SMS), Whatsapp group. Ketiga, perbincangan-perbincangan ringan. Kesemuanya bukan hanya sekedar motivasi berhijab syar'i, namun pengetahuan berbagai hal seperti pengetahuan tentang permasalahan kewanitaan lainnya yang masih dalam konteks ajaran dan tuntunan agama Islam. Namun, hasil dari langkah-langkah tersebut hasilnya belum terlalu signifikan. Seperti ungkapan kiai berikut ini dalam sesi wawancara:

'kalau hasil....kami belum maksimal, karena menurut kami kemajuan trend itu lebih kuat, tapi ya.....semuanya itu akan kembali pada masing-masing individu. Namun kami tetap selalu menyampaikan yang terbaik pada warga kami, karena merupakan bagian tanggungjawab kami untuk menyiarkan kebaikan dan mengamalkan keilmuan yang kami miliki.'

Selain itu pengetahuan tentang keislaman secara mendalam akan berpengaruh terhadap keputusan seseorang dalam berhijab. Semakin tinggi pengetahuan seseorang memahami Islam secara komprehensif maka semakin matang pula seseorang dalam menjalankan seluruh perintah dan laranganNya. Pengetahuan berhijab dapat dipelajari dari ajaran agama Islam melalui ayat tentang pakaian seperti dalam firman Allah SW'T yang artinya:

"Wabai anak cucu Adam! Sesunggubnya Kami telab menyediakan pakaian untuk menutupi auratmu dan untuk perbiasan bagimu.Tetapi pakaian takwa, itulah yang lebih baik. Demikianlah sebagian tanda-tanda kekuasaan Allah, mudah-mudahan mereka ingat"'(Q.S. Al-A'raf, 7: 26)

Ayat tersebut telah mengisyaratkan bahwa dalam berpakaian seorang muslimah telah diatur dalam Al Quran yang tujuannya tidak lain adalah menjaga kehormatan seorang wanita muslimah baik ketika beribadah ataupun dalam pergaulan sehari-hari. Adapun batasan aurat bagi laki-laki adalah antara bagian anggota tubuh pusar dan lutut, sedangkan perempuan meliputi seluruh tubuh kecuali telapak tangan dan wajah.

Menutup aurat dapat memberikan beberapa manfaat, di antaranya adalah: (a) Allah SWT memerintahkan wanita untuk menggunakan hijab demi kepentingan dan kemaslahatan wanita itu 


\section{Tadrisuna}

Jurnal Pendidikan Islam dan Kajian Keislaman

sendiri (b) Allah SW'T memerintahkan wanita untuk memakai hijab, agar kulitnya terlindung dari sesuatu yang merugikan (c) Menggunakan hijab tidak hanya menghindarkan tubuh dari sinar matahari, tiupan angin kencang dan polusi udara, serta dapat memproteksi kulit dari pengaruh buruk lingkungan. ${ }^{20}$

\section{Kesimpulan}

Berdasarkan hasil olahan dan analisis data yang telah penulis lakukan, maka dapat disimpulkan bahwa memakai hijab syar'i di kalangan wanita masih sebatas mengikuti trend berbusana kekinian. Sehingga yang dengan mengikuti trend tersebut maka berbusana pun mudah berganti-ganti model sesuai dengan kondisi dan mode saat itu. Selain itu berhijab syar'i masih bersifat sementara (lepas pakai) sesuai dengan kondisi dan situasi.

Sehingga motivasi yang lebih dominan dalam dan nampak dalam berhijab syar'i adalah motivasi psikologis, dari motivasi tersebut dapat membentuk polarisasi berbusana dan berpakaian seperti berpakaian dengan beragam motif, model dan warna. Hanya saja manutup seluruh anggota tubuh. Disamping itu kurangnya pengetahuan tetang keislaman seperti perintah menutup aurat, batasan aurat yang harus ditutup, manfaat menutup aurat. Hal demikian belum sepenuhnya dijiwai dan dipraktikkan dalam kehidupan nyata.

\section{DAFTAR PUSTAKA}

Syuqqah, Abu. Busana Dan Perhiasan Wanita Menurut Al Quran Dan Al Hadist. cet ke I. Bandung: Mizan, 1998

Purnama, Yulian., ’Makna Hijab, Khimar dan Jilbab” Buletin At Tauhid, 5 Januari 2018

Haromaini, Nurul, "Studi Analisis Pemaknaan Hijabers Community Surabaya terhadap Hijab dalam Film 99 Cahaya Di Langit Eropa”. Commonline Departemen Komunikasi vol. 3. No 3

Yohana, Nova - Dadi Ahmadi, “Konstruksi Jilbab sebagai Simbol Keislaman” Jurnal Mediator Vol. 8. No 2, 2007

Putri, QQ Presika Jati., Skripsi: Pengaruh Pemakaian Hijab Syari terhadap Interaksi dengan Lawan Jenis”. Jakarta: Fakultas Ilmu Tarbiyah dan Keguruan Uin Syarif Hidayatullah, 2017

Unu, Hamzah B. Teori Motivasi dan Pengukurannya. Jakarta: Bumi Aksara, 2008

Sondang P, Siagian. Teori Motivasi dan Aplikasinya. Jakarta: Rineka Cipta 2004

Sudirman A.M. Interaksi dan Motivasi Belajar Mengajar. Jakarta: Rajawali Pers. 2011

Nasir, Nurlatipah, "Kyai dan Islam dalam Mempengaruhi Perilaku Memilih Masyarakat Kota Tasikmalaya” Jurnal Politik Profetik Vol 6 Nomor 2, 2005

${ }^{20}$ Mohd Fuad Fachruddin, “Aurat dan Jilbab dalam Pandangan Mata Islam” (Jakarta: CV Pedoman Ilmu Jaya, 1991), 39 


\section{Tadrisuna}

Nasution, Robby Darwis, "Kyai sebagai Agen Perubahan Sosial dan Perdamaian dalam Masyarakat Tradisional” Jurnal Sosiohumaniora. Vol. 19. No. 2. 2017

Muhajir, Noeng. Metodologi Penelitian Kualitatif. Edisi II. Yogjakarta: Penerbit Rake Sarasin, 1996

Fachruddin, Mohd Fuad. "Aurat dan Jilbab dalam Pandangan Mata Islam”. Jakarta: CV Pedoman Ilmu Jaya, $1991^{21}$

\section{Format Penulisan Refrensi.}

Refrensi menggunakan catatan kaki (Footnote) dengan Turabian Style Fullnote. Contoh ${ }^{22}$

\section{Penulisan Daftar Pustaka}

Nama Belakang(Koma) Nama depan (Titik) Judul Buku (Italic), Penerbit. Tahun

$\mathrm{Buku}^{23}, \mathrm{Jurnal}^{24}$

\section{Contoh :}

\section{Buku}

Reason, Peter, and Hilary Bradbury. Handbook of Action Research: Participative Inquiry and Practice. Sage, 2001.

Rinaldi, Reza Adji, Lily Mauliani, and Finta Lissimia. "PENERAPAN KONSEP RAMAH ANAK PADA RUMAH SUSUN SEDERHANA.” PURW ARUPA Jurnal Arsitektur 1, no. 1 (2017): $17-22$.

21

22 Peter Reason and Hilary Bradbury, Handbook of Action Research: Participative Inquiry and Practice (Sage, 2001).

${ }^{23}$ Ibid.

${ }^{24}$ Reza Adji Rinaldi, Lily Mauliani, and Finta Lissimia, "PENERAPAN KONSEP RAMAH ANAK PADA RUMAH SUSUN SEDERHANA,” PURW ARUPA Jurnal Arsitektur 1, no. 1 (2017): 17-22. 